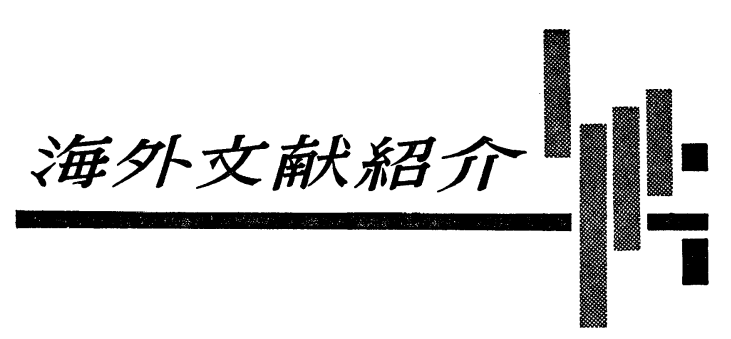

68-126重力傾斜形衛星用ロング V アンアナ

E. J. Perroti, R. W. Gollhardt, R. E. Roris: The long vee as a gravity gradient satellite antenna, The Microwave Journal, Dec., (1967), 47

衛星通信計画が航空機や船舶を含む範囲まで拡大され ると, 当然 $225 \sim 400 \mathrm{MHz}$ 帯が考慮の対象となってくる が，乙の帯域で充分な利得を有するアンテナシステム は, 衛星自体より大きくなっていまい, 衛星の要求から は当然軽量でなければならず, 太陽電池に影を落した り，他のアンテナを影にしてもならない.

こうした矛盾を解決する一方法として，乙こでは常に 地球を指している重力傾斜衛星のブームに目をつけ，乙 れを 2 本のロングワィヤーアンテナに拉きかえて, 両目

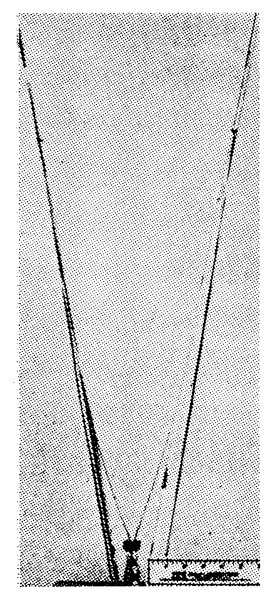

写真 1

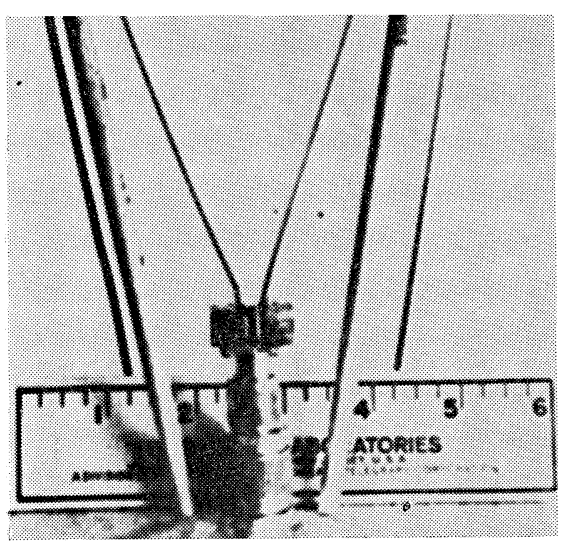

$486(62)$

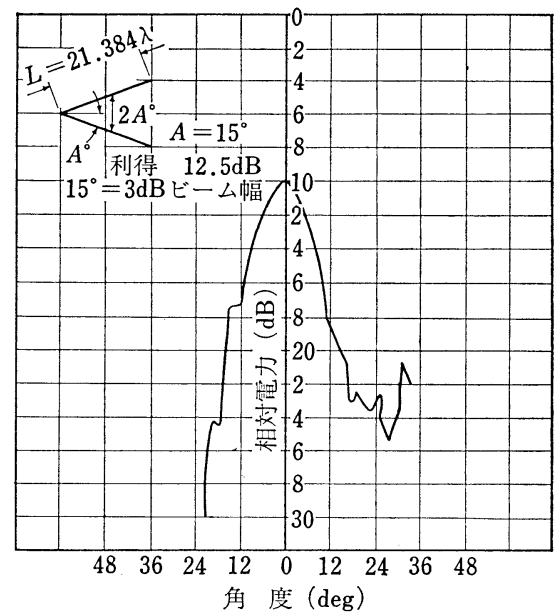

図 1(a)

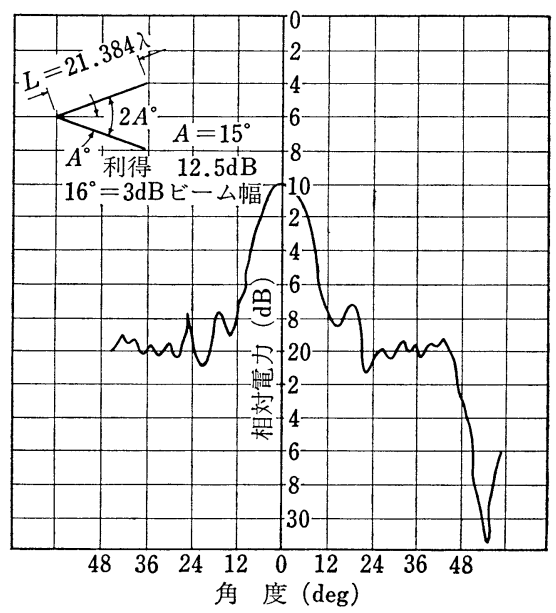

図 1(b)

的を達成させるものである. 定在波形のVアンテナの垂 直面内の正規化電界強度は,

$$
E_{T}=\left[\frac{\sin \left(\frac{N \pi}{2} \cos A \cos \psi\right)}{1-\cos ^{2} \phi \cos ^{2} A}\right]
$$

ことに罡N: 各ワイヤーの半波長に対する比

$$
\begin{aligned}
& A: \mathrm{V} \text { 頂角の } 1 / 2 \\
& \phi: \mathrm{V} \text { 面から測った角度 }
\end{aligned}
$$

で表わされる。この式より同期高度に対する地球を見込 む角度17〜22 度を満足するアンテナ長 $21.384 \lambda$ および 頂角"12.5２2 度を選定し，写真1，写真 2 のようなス ケールモデルにより利得，指向性の測定を行なった結果 を，15度预よび 12.5 度の場合につき図示しているが， ことでは 15 度の場合を示す。 その結果は若干理論值と 異なるが，乙の結果から次のアンテナ寸法を決定してい る.

$\begin{array}{ll}\text { アンテナアーム長 } & 85.54 \mathrm{ft} \\ \text { 頂 角 }(2 A) & 27 \text { 度 } \\ \text { 最大頂角変化 } & \pm 1.25 \text { 度 }\end{array}$


ビーム幅(アンテナ面内) 18 度

(垂直面内) 15 度

利 得 $12 \mathrm{~dB}$

てのアンテナの給電構造は，マジックТハイブリッド を用いてパワーを等分し，くり出し機構を介して 2 本の ブームに給電するようになっている。

(委員 安田・紹介者 長谷部望)

\section{8-463 時分割多元接続衛星通信実験}

Tadahiro Sekimoto, John G. Puente: A Satellite Time-Division Multiple-Access Experiment, IEEE Transactions on Communication Technology, Vol COM-16, No., 4, Aug. (1968), 581-588

衛星通信には方式固有の利点として，互いに遠く離れ た多数の地上局が 1 個の衛星中継器を介して相互かつ同 時に通信すること(多元接続) の可能性がある. 本論文 では時分割多元方式 (TDMA) の利害得失を周波数分割 多元接続方式 (FDMA) のそれと対比するとともに, TDMA の有用性を指摘し，TDMA を開発する場合の 主要研究問題点が同期系の精度向上にあるととを述べた うえで，商用通信として実用化する場合に必要となる データを得ることを目的として試作した実験装置（3地 上局分）の構成，ならびにインテルサット 1 号赭星を用 いて行なった現場試験の結果について述べてる。

ここで採用したTDMA 方式のフレーム構成は図 1 の とおりである. 1 フレーム $(125 \mu \mathrm{s})$ は 3 局バースト信号 からなり，各局バース卜信号 $(41.67 \mu \mathrm{s})$ は前置確定パ ターンおよび情報符号で構成される。前置確定パターン は次の 2 種類のパターンからなる。

（1） PCM-PSKの復調に必要な搬送波およびクロッ ク同期回復用符号.

（2）局符号識別ならびにワードおよびバースト同期 飞用いられるユニークワード.

各局の実験装置は，（1）PCM 端局装置，（2）同期制 御装置, ( 3 ) PSK 変復調装置, の3 装置で構成されて

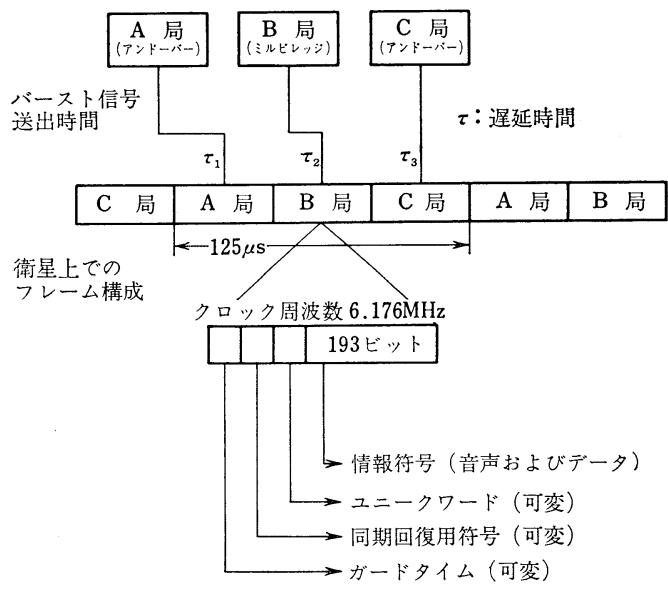

図 1 TDMA フレーム構成
おり，搬送波同期回復用符号数，クロック同期回復用符 号数，およびガードタイムを可変パラメーターとした実 験が可能になっている。

PCM 端局装置はすでに商用化されている PCM-24 ch 方式用のあのである.

同期制御装置は各局バースト信号をあらかじめ定めら れたタイムスロットに配置（アクジション），その同期 を維持するためのあので, メモリー, 前置確定パターン 発生器, バースト同期回路からなる。乙の装置の動作原 理, 理論的解析,ならびに実験結果は下記の Companion Paper に詳細に論じられている.

\section{8-464}

O. Gene, Gabbard: Design of a Satellite TimeDivision Multiple-Access Burst Synchronizer, IEEE Transactions on Communication Technology, Vol. COM-16, No. 4, Aug. (1968) 589-596

PSK 変復調装置はクロック周波数 $6.176 \mathrm{MHz}$ ，搬送 波中間周波数 $70 \mathrm{MHz}$ で動作する 2 相差動位相変調器と 同期検波器とからなり，クロック同期回復時間短縮のた めの回路が付加されている.

実験の結果から次のことが指摘されている。

(1) PCM 端局装置, 同期制御装置, PSK 変復調装 置はそれぞれ所期のとおり動作しうるとと.

（2）ガードタイムは静止衛星を対象とする場合は約 $100 \mathrm{~ns}$ (衛星の位置変化を常時予測する方法を用いれば 約 $2 \mathrm{~ns}$ ) 以下にしうるとと.

（3）衛星の位置変化情報を用いた電算機予测による 方法によってアクジションの精度は約 $\pm 2 \mu \mathrm{s}$ 以下にする ことが充分可能なとと。

（4）ユニークワードの符号数は15ビット以上であれ は充分実用的であるとと.な掞てのユニークワードの構 成と検出方法ならびにバースト同期の安定性については 下記の Companion Paper に詳述されている。

\section{8-465}

Winfried Schrempp and Tadahiro Sekimoto: Unique Word Detection in Digital Burst Communications, IEEE Transactions on Communication Technology, Vol. COM-16, No. 4, Aug., (1968), 597-605

本論文で諭じられている PCM-TDMA 衛星通信方式 については，近年，わが国であ各方面で進められてお り，本論文はこの分野に関連する研北者にとって一読の 価值がある。 (委員 伊藤・紹介者 平出賢吉)

\section{8-485 赤外線像のカラー写真変換}

L. W. Nichols, J. Lamer: Conversion of Infrared Images to Visible in Color, Applied Optics, Vol. 7, No. 9, (1968), 1757-1762

本装置は，物体の放射，反射による赤外線を， 3 波長 
帯に区分し, おのおの, 赤外線検出器によって検出し, その出力を, 三原色に対応させて, カラー写真を作成す るあのである。

図 1 で示すように，六角形の走査ミラーを上下，左右 に回転させることによって，影像を垂直および水平にラ

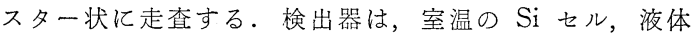
窒素で冷却した $\mathrm{InSb} セ ル$, 液体水素で冷却した $\mathrm{Ce}: \mathrm{Hg}$

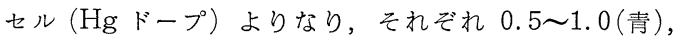
$3.0 \sim 5.5$ (緑)，8～14(赤） $\mu$ の波長带を分担し，長波長 は検出感度によって決定され，短波長はカットフィルタ 一を使用する。おの打の同一地点からの放射を受けうる ように，3個並んで組みこまれ，Siを除いて冷却瓶の空 にベローズのついた非球面対物レンズを有し，解像度 1 $\operatorname{mrad}$ になるよう，アパーチャーを備えている．

検出する信号は，チョッパーによって交流増幅が可能

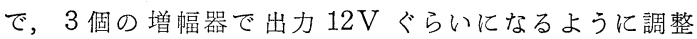
される.その出力信号で 3 個の光変調管を変調し，おの おのが $R, G, B$ 光源となるように色分解フィルターを通 過させたのち合成し，フィルムを露光する.とのとき， 六角形のミラ一回転は, 受光と対応してフィルム上を走 査できる.なお, 光源の光量は, $1 \mathrm{mrad} の$ 解像度を有 するように，ピンホールで平行部のみ利用しているが,

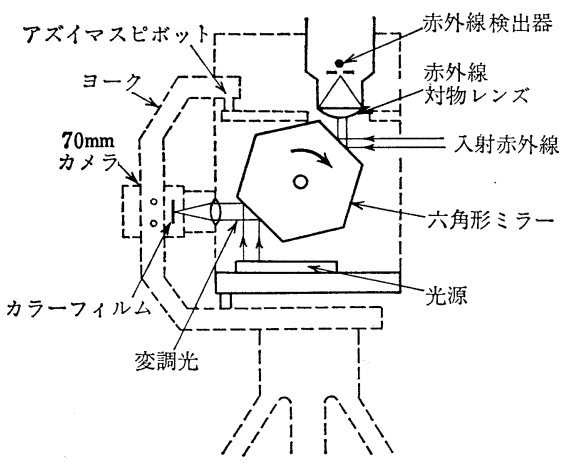

図 1 装置の断面図

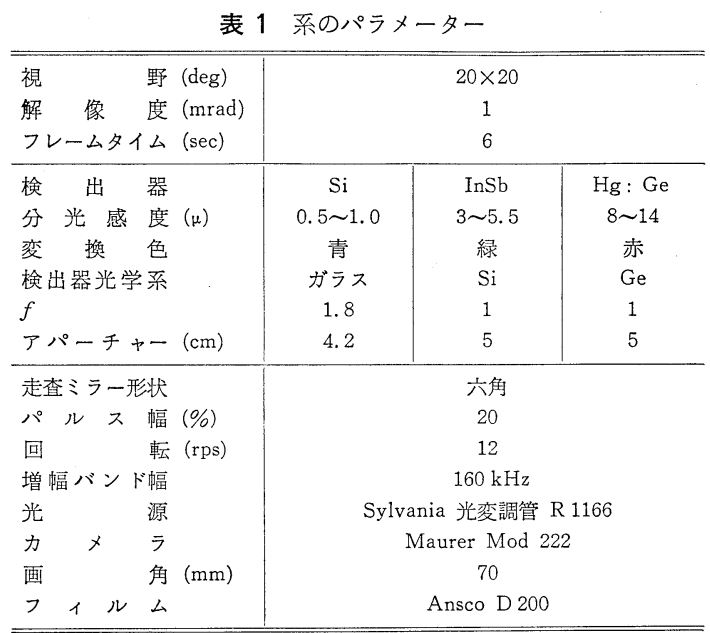

$488(64)$
充分目的が果たされた。ミラ一の回転やパルス幅その 他，系に使用されるパラメータ一は表 1 に掲げてある.

実際の物体色とは無関係であるが，上記の装置で得ら れたカラー写真は, 非常に抒むしろい情報を含んでいる。

たとえば，青は反射や太晹の散乱光に起团し，赤は放 射による, 緑は単独であまり現われないが，赤や青に加 わり，オレンジや黄色を作る。具体的には，空は青く映 じ，特に澄んだ日などは， $60 \mathrm{~km}$ 遠力の水平線す明確な コントラストを得る。また湿った暖い日は赤く映る。 $\mathrm{CO}_{2}$ を含む排気ガスは単独の緑となり，新車や美しい車 は青く，中古車やよごれた車はオレンジに，また，氷の 中でもタイヤは赤く䘄いて映る.さらに興味あるのは, $5 \sim 10$ 万年前に火山活動のあった地域はいまもなおその 熱の存在を見るととができる。人体は血液循環のため黄 色く映じ, 衣服は赤く映る. 積雲は上部は青く下部は赤 く映る.このことは雲が地球の保温に役立っているとと を意味する。

以上のように，真夜中においても，昼と同様，われわ れをつつむ環境の温度分布や反射特性を钼察するのに有 力な手段を与えるあのである.

(委員 鈴木・紹介者 泉 善博)

\section{9-19 主観色テレビ}

James F. Butterfield: Subjective (Induced) Color Television, Journal of the SMPTE, Vol. 77, No. 10, Oct., (1968), 1025-1028

主観色の現象を利用し，白黒テレビの機材でカラ一画 像を撮像，再現する方法について述べられている.

図1に示すような白黒図形の円板 (ベン八ムのコマ) を適当な周波数で回転すると色が見える．との色を主観 色という。ベン八ムのコマで見られる主観色には次のよ うな法則がある。

円板を時計または反洔計のいずれの方向に廻しても， 黒の半円の次に現われる黒線は赤色がかった円に見え, その次に現われる黒線は緑色に，そして黒の半円の前に 現われる黒線は青色の円に見える，線の位置，長さ，太 さなどによって色相が変わり，また，黒部分の大きさや 照射条件, 回転数 $(3 \sim 10 \mathrm{~Hz})$ によって彩度, 色相が変化 する。

上記の現象をテレビに応用すると，白黒テレビのカメ ラ，およびモニターで主観色を見ることができる．図 2

図 1 ベン八ムのコマ

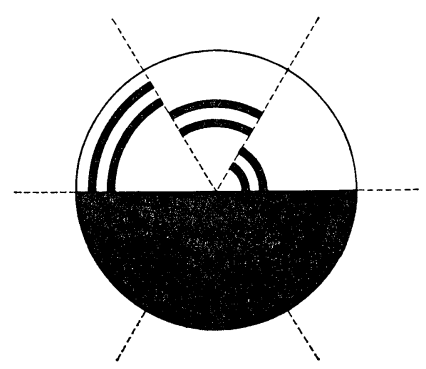

テレビジョン 


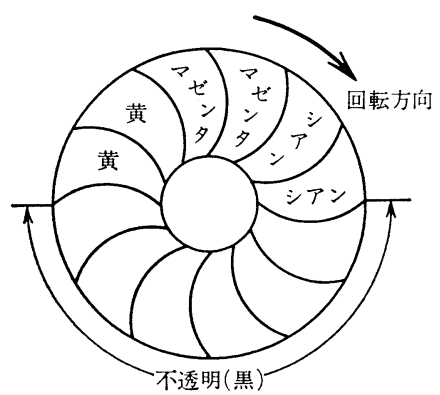

図 2 フィルター円板

に示すような主観色変換器と称するフィルター円板を, 白黒カメラの前でフィールド周波数の 12 分の 1 で回転す る. 最初の 6 フィールドは不透明で, ベンハムのコマの 黒半円に相当する. 次の 2 フィールドはマイナス赤，す なわちシアンフィルターであり, 赤の被写体は黒とな る.とれら 2 フィールド画面の黒は大面積黒の次にある ので, 前述の法則により赤の主観色を発生する. 同様 に, 次の 2 フィールドはマイナス緑(マゼンタ), また, 次の大面積黒の前の 2 フィールドはマイナス青（黄）の フィルターで，扣のおの緑，青の主観色を発生する.

白黒モニタ一上で見ると， $5 \mathrm{~Hz}$ のフリッカーと同時 に，半分ほど飽和した色を見るととができる．撮像管や モニタ一の調整, 特に照明によって結果は大きく左右さ れる. 灭色背景の小さい色の被写体が最む効果的に再現 される.

主観色テレビはフリッカーはあるが，NTSC方式など にくらへて簡便, 低廉であるので, 工業用, 教育用, 医 用, 海洋学, その他に応用可能である.

(委員・紹介者 守田)

\section{7-211 空気式ファーストプルダゥンを \\ 67-212 用いた $16 \mathrm{~mm}$ カラーフィルム スキャナーの設計}

Heinrich Zahn, Emil Sennhenn: Mechanical and Electronic Layout of a Color $16 \mathrm{~mm}$ Scanner with Pneumatic Fast Pulldown/Fast-Pulldown Mechanism for Film Scanning, Journal of the SMPTE, Vol. 76, No. 6, June, (1967), 535-539/540-544

このプルダウン時間は, $1.14 \mathrm{~ms}$ で, FCC 規格(最大 垂直帰線時間 $1.33 \mathrm{~ms})$ によるフィルム送像に適合でき る.

このようなファーストプルダウンと FSS を組合せた カラーフィルムスキャナーは, レジストレーションの調 整がまったく不要であり, 光学系が単純で効率が高いと いう特長がある反面，FSSに用いる残光時間の短いスキ ヤンニングチューブは, 赤色光の放射が少ないという久 点があるが，乙れについては主成分にP24を用いた螢光 体を使用し，特殊な処理と塗布方法によって赤色光をか なり増加させるととが可能になった.

フィルムに加わる力が最小となるようにプルダウンさ

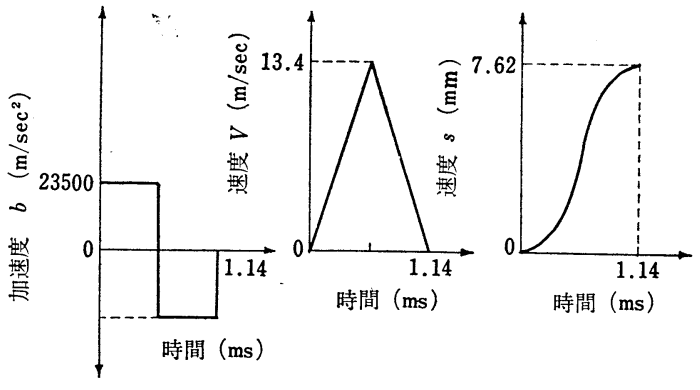

図 1 ファーストプルダウンの理想的動特性

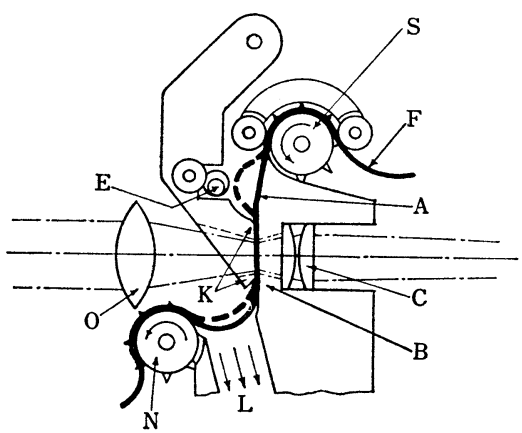

A 衝突面， B ピクチャーゲート， C 集光レンズ， E 偏心 シャフト, F フィルム, $\mathrm{K}$ クランピングゲート, L サクシ ヨン, $\mathrm{N}$ 連続回転スプロケット，O レンズ， S 間欠スプロ ケット

図 2 空気式間欠フィルム送りの図解

せるには，プルダウン時間の前半において均一に加速 し， 1/2 コマ長だけフィルムを前進させて，後半におい て均一に減速すればよい，乙れに要する加速度 $a$ は, $a=2 S_{a} / t_{a}{ }^{2}=23453 \mathrm{~m} / \mathrm{sec}^{2}$

ととに $S_{a}=3.81 \mathrm{~mm}:$ フィルムの $1 / 2$ コマ長 $t_{a}=0.57 \mathrm{~ms}$ ：プルダウン時間の $1 / 2$

プルダウン部のフィルム質量 $m$ は, $0.0168 \times 10^{-3} \mathrm{~kg}$ であるので, フィルムに加わる力 $F$ は，

$$
F=m a=0.397 \text { ニュートン }
$$

理想的動特性を図 1 亿示す.

次にプルダウンの動作を図 2 にって説明する.

静止状態に打いては，フィルムFはクランピングゲー トKによって，ピクチャーゲートBに押付けられてい る.上方のスプロケット $\mathrm{S}$ は，ピクチャーゲートKの手 前に 1 コマ長のフィルムループをつくるよう間久運動を 行なう。ピクチャーゲートKの下に第 2 のループがあ り，そのループの下にサクションLが組込まれている.

下方のスプロケット $\mathrm{N}$ は $188.2 \mathrm{~mm} / \mathrm{sec}$ の平均フィルム 速度に従って連続的に回転する。いま，垂直帰線期間に 偏心シャフトEによってゲートKが解放されると, フィ ルムFはサクションLによって図の点線の位置から実線 の位置まで引張られる，このとき，上方ループの下に圧 縮された空気は，フィルムの運動に強い減速効果を与え る.フィルムが停止すると，クランピングゲート K 代閉 じられて，次の周期がはじまる．2-3プルダウンを行な 
わせるため, 偏心シャフトEとスプロケット Sには，ダ ブルクランクと称する特殊なリンク機構が用いられてい る。

主要性能を要約すると,

(1) 輝度チャネルの $\mathrm{SN}$ 比: $43 \mathrm{~dB}$ (ガンマ0.4, 濃 度 0.45$)$

（2）瞬時起動： $0.2 \mathrm{sec}$ 以内（画，音とも）

(3)画ぶれ: 水平 $0.1 \%$ 以下, 重直 $0.2 \%$ 以下(画 面の横幅を基準)

(4) 音声のワウ,フラッター： $\pm 0.2 \%$ 以下

$(5 \mathrm{kHz})$

(委員 藤尾・紹介者 種田悌一)

\section{8-307 $60 \mathrm{MHz}$ ビデオシステム用半導 体低雑音前置増幅器と受像管駆 動増器幅}

O. H. Schade, Sr.: A Solid-State Low-Noise Preamplifier And Picture-Tube Drive Amplifier for A 60 $\mathrm{MHz}$ Video System, RCA Review, Vol. 29, No. 1, March, (1968), 3-21

MOS 形FETを用いた高帯域前置增幅器とプレー ナートランジスタを用いた受像管駆動回路について述へ られている。

\section{(1) 前置増幅器}

相互コンダクタンスが $10 〜 15 \mathrm{~m}$ の MOS 形トラン ジスタの開発によって, 低雑音の広带域前置増幅器の設 計が可能となった。

高精度テレビシステムの設計には特別の注意が必要で ある. 高解像力蓄積面からの光電信号を直接増幅器に入 れると, 増幅器のノイズのために系の解像力が制約され る.そこで，信号源としては，マルチプライヤ一付高解 像力ビジコンを用いる. 、ルチプライヤー出力電流中の $\mathrm{SN}$ 比としては，带域幅 $60 \mathrm{MHz}$ で $40 \mathrm{~dB}$ が得られる.

マルチプライヤーの負荷抵抗 $R$ に増幅器初段のカス コード增幅器の入力容量と回路の浮遊容量の和 $C$ が並列 に接続されるために，信号電圧は周波数に逆比例する. 增幅器の後段でこれを修正しているために, 入力段では いるホワイトノイズは, 補正の後で周波数に比例するノ イズになり, 增幅器の入力における等価実効ノイズ電圧 $E_{n}$ の理諭值は,

$$
E_{n}=\frac{2.6 \pi}{\sqrt{3}} R C \times 10^{-10}\left(R_{e q}\right)^{1 / 2}(\Delta f)^{3 / 2}
$$

したがって，

$$
\mathrm{SN} \text { 比 }=2.13 I_{S} \times 10^{9} / C\left(R_{e q}\right)^{1 / 2}(\Delta f)^{3 / 2}
$$

となる、ここで， $R_{e q}$ は等価ノイズ抵抗， $\Delta f$ は带域 幅， $I_{S}$ は信号電流である。したがって，当然 $C$ はでき るだけ小さくするべきである． $E_{n}$ の実测值は $0.68 \mathrm{mV}$ である、また，第 2 段以後の系がノイズに寄与する割合 は $6 \%$ に過ぎない. 増幅器の出力信号レベル $1 \mathrm{~V}$ に対す る $\mathrm{SN}$ 比を $40 \mathrm{~dB}$ とするためには，ノイズ電圧は $10 \mathrm{mV}$

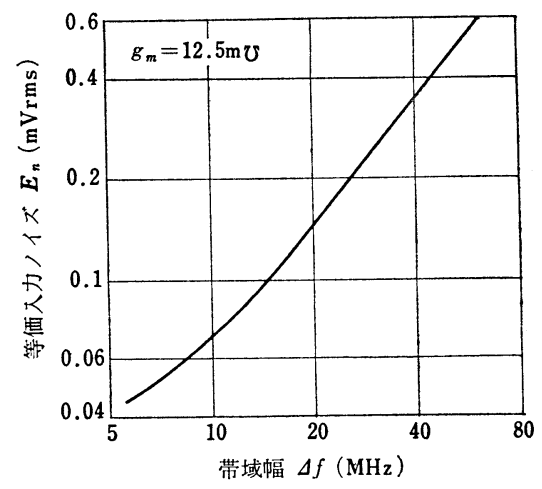

図 1 MOS カスコード前置増幅器の等価実効入力 ノイズ電圧と帯域幅との関係

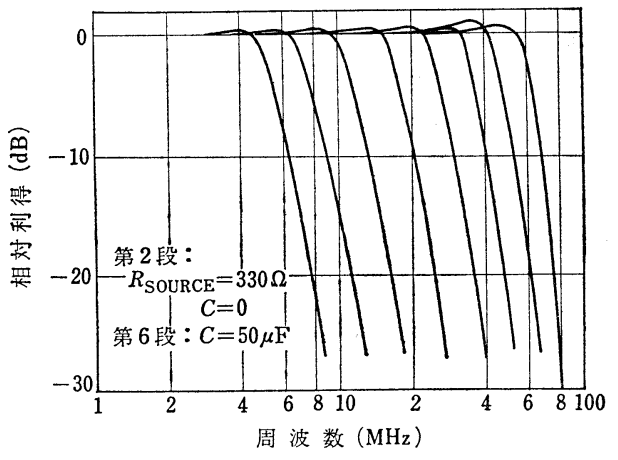

図 2 前置增幅器の映像通過帯域

以下でなければならず，増幅器での許容ノイズ増加量を $1.6 \mathrm{~dB}$ とすると, 増幅器の低周波利得は約 10 飞制限 される. 增幅器の利得は, ノイズとの関連で周波数帯域 によってきまる. 入力ノイズ $E_{n}$ と帯域幅 $\Delta f$ の関係 を図 1 に示す.

MOS 形デュアルゲートトランジスタを用いた前置増 幅器の周波数特性を図 2 亿, 回路構成を図 3 亿示す. 第 2 段と第 6 段はアパーチャ一補正, 第 3 段が入力容量に よる高域低下に対する補償回路, 第 5 段が位相等価器, 第 7 段が低域沪波器を含む出力回路である.

段閒の結合沪波器は修正 $\pi$ 形沪波器で，2つの抵抗の いずれか一方または両方の值を調整することによって， 周波数レスポンスを平坦にするととができる.

アパーチャー補正は，第 2 段と第 6 段のソース抵抗に and/orのバイパスを設けることによって行なっている. 增幅器の低周波利得を下げ，その低下分をマルチプライ ヤー利得の增加で補償するととによって, 増幅器のノイ ズレベルの増加を防止している.

沪波器の位相特性の補正は, 第 5 段の次にある位相補 正回路で行なっている.

\section{（2）受像管駆動回路}

図 4 に示す受像管駆動用カスコード回路は $90 \Omega$ ライ ンから直接駆動される. カスコード回路の電压利得は 32 であり，ブランキングを含む最大映像信号出力は $50 \mathrm{~V}$ 

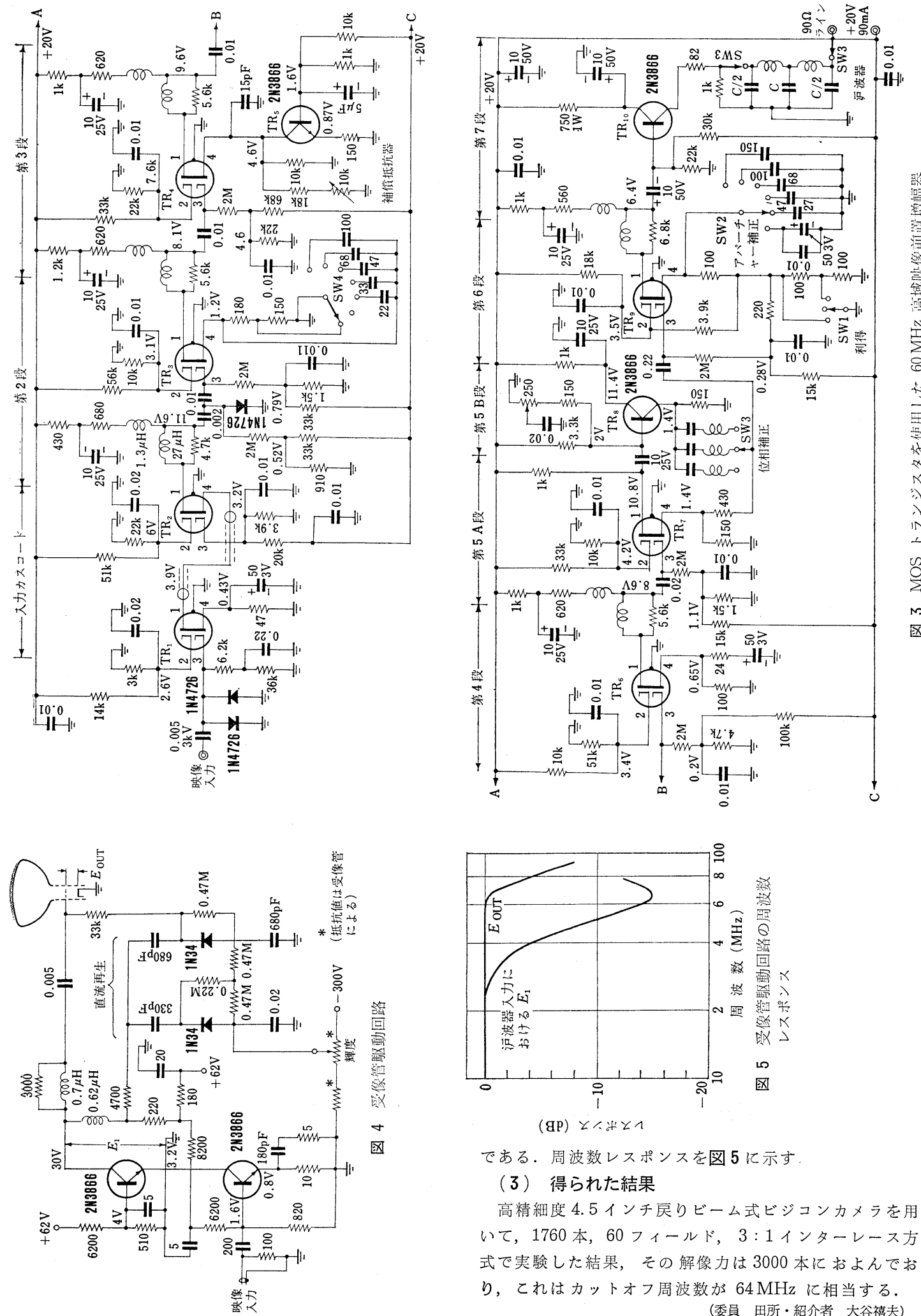

(gp) $\measuredangle \ll$ i\# $\measuredangle 1$

である.周波数レスポンスを図 5 に示す

(3) 得られた結果

高精細度 4.5 インチ戻りビーム式ビジコンカメラを用 いて, 1760 本, 60 フィールド, 3:1インターレース方 式で実験した結果, その解像力は 3000 本におよんでお り，てれはカットオフ周波数が $64 \mathrm{MHz}$ に相当する.

(委員 田所 - 紹介者 大谷禧夫) 


\section{8-503 電子的網点写真}

R. L. Hallows, Jr., R. J. Klensch: Electronic Halftones, IEEE Spectrum, Vol. 5, No. 10, Oct., (1968), 64-72

新聞や書物の印刷のオートメーション化のために, ドットパターンによるハーフトーンを電子的に発生する 方式が研究されている。本文は高解像度 CRTをディス プレイに用いた電子的ハーフトーン技術の実験装置につ いて述べている.

ドッド配列はサンプリングラスター構成によって $45^{\circ}$ に並んだ新聞形式か，六角形式をとるととができる．各 ドットの面積は原画の透過率の関数で, CRTの電子ビー ムにより希望するドットサイズになるまで，ら施状に走 查する．乙のとき半径が增加するにつれて走查速度が増 し，露光したフィルムの濃度が低下するので，半径の増 加に従って円走査の回数を増加させる.

ハーフトーンは，黒地に白のドット，または白地に黒 のドットとして表わすととができる。

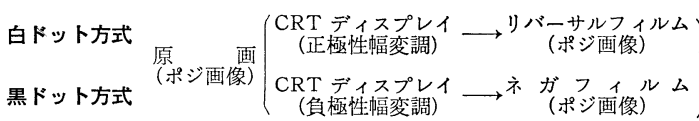
—高コントラストネガフィルム—印刷プレート—卵刷物

黒ドット方式は，活版印刷と同様なプロセスなので， 印刷界の一部で好まれているが，ての方法では小さな ドットを 2 つのきな值の間の一様な小差として表わす ためのむずかしさがあり，たとえば，110線のスクリ一 ンで 19 対 1 のコントラスト比を得るために，偏向回路 のダイナミックレンジが約 $120 \mathrm{~dB}$ 必要であり, 電源八 ムなどの妨害に対しては白ドット方式のほうが析違いに 有利である。

ら施走查洔間をきめるパルス幅変調波を得るのには，
(1) 図に示すように画像信号を積分回路を通して シュミットトリガー回路に加える.

(2) 画像信号にのてぎり波を重畳してシュミットト リガー回路に加える.

の 2 つ方法がある.ガンマー補正は非直線のとぎり波 を用いて行なうととができる.

上記のように，ドットの寸法を変化する方法は，ドッ 卜の空間周波数は一定で振幅が変化するから，振幅変調 方式というととができる。乙れに対して，一定サイズの ドットの間隔を変化する周波数変調方式が考えられる.

この場合, 最底濃度は微細構造の識別のためにドット 間の最大間隔が押えられることからきまって，

$$
D=\log \left(\frac{T_{\mathrm{ON}}+T_{\mathrm{OFF}}}{T_{\mathrm{OFF}}}\right)
$$

で与えられる。いま，印刷するスポットが 3 mil 角の正 方形で，記録スポットはウォブリングが非対称アパー チャーで縦方向が $3 \mathrm{mil}$, 走查方向が $1.5 \mathrm{mil}$ の方形之 する。スポット速度を $0.15 \mathrm{mil} / \mathrm{ms}$ とし，最大ドット間 隔を $10 \mathrm{mil}$ とすれば， $T_{\mathrm{ON}}=10 \mu \mathrm{s} ， T_{\mathrm{OFF}}=56.7 \mu \mathrm{s}$ とな るから，Dう0.07 となる。

印刷で得られる最大濃度は 1.4 程度であるので, 1.4 一 $0.07=1.33$ の濃度範囲が得られる。との方式では，一定 濃度の広面積部分で低速走查の方向に線構造が現われ妨 害を与えるので, 変調回路の画像入力にランダムノイズ を加えて線構造を目立たなくするととが行なわれる. さらに，ドット間隔を高速走査の方向のみでなく，その 直交方向にも変化させる, 両方向 FM システムも研究さ れている．周波数変調方式によれば，回転円筒形の走査 機構を用い，パルス周波数変調されたレーザー用いて直 接印刷用プレートに画像を彫り込むととができるという 利点がある. AM 方式, FM 方式いずれも実験段階にあ， り，実用装置開発には，さらに研究が必要である。

(委員 斎藤・紹介者 町田正彦)

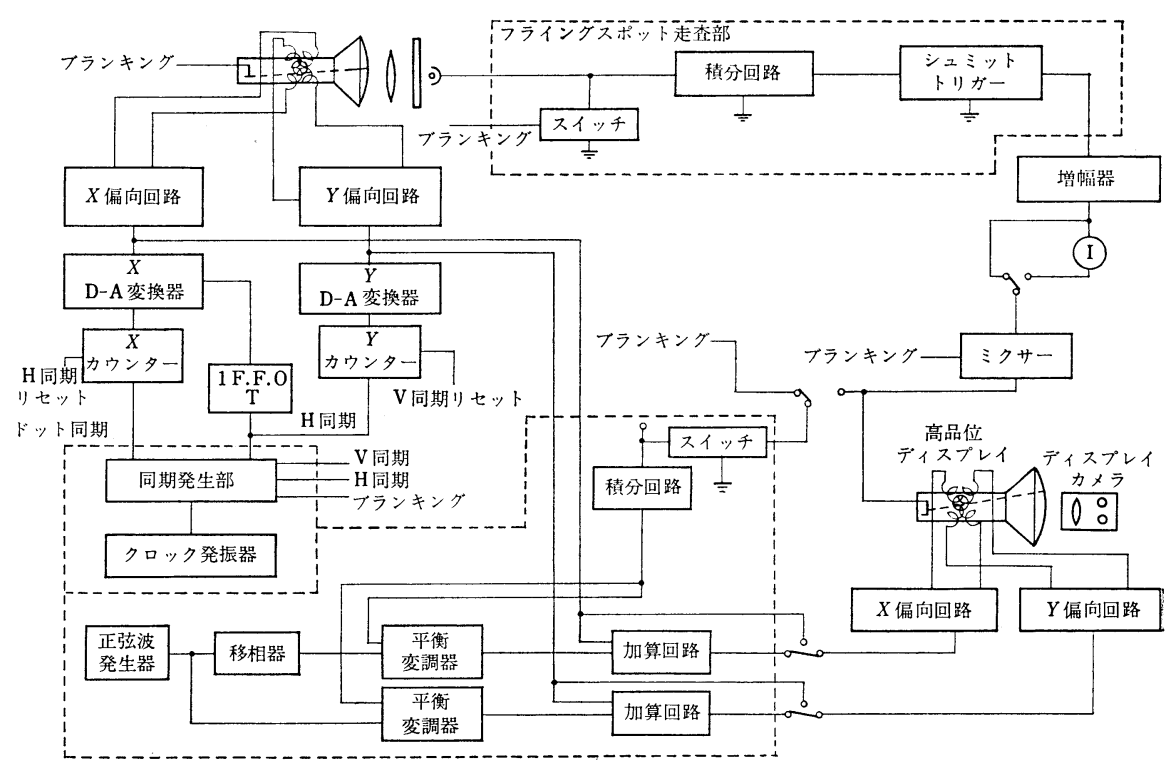

図 1 ら旋走查ドットを用いた実験ハーフトーン装䇫系統図 